\title{
A Case Study of Tourists' Perceived Motivation and Impacts of Sport Tourism Event*
}

\author{
Guo Yingzhi, Li Xiaoming, Daizy Liu \\ Fudan University, Shanghai, China
}

\begin{abstract}
This article is mainly based on the perspective of tourists, with first-hand data that were collected by questionnaire-based surveys to investigate tourists' participation as well as motivation, to evaluate the perception of Asian Winter Games of 2011. It also explores frequency of tourists’ participation in sport tourism in the past years, motivation factors, and relationship among the impact factors. This was collected, in order to provide government organs with indicators of when they should hold sport events, valuating the various types of profits and benefits, and how to attract more tourists to participate, in order to better facilitate and promote the development of sport tourism, while providing a scientific basis for future reference. Through using an empirical investigation of the tourists' influence perception evaluation in Kazakhstan Asian Winter Games, this study provided a scientific basis for past and future references.
\end{abstract}

Keywords: sport tourism event, tourists’ perceived motivation, Asian Winter Games, tourism impact, Kazakhstan

\section{Introduction}

Asian Winter Games is the "winter” part of Asian Games and occurs every four years. It is the world's second biggest sport event after Winter Olympic Games. Asian Winter Games usually takes turns to be held by the most developed countries in Asia, such as Japan, South Korea, and China. The 7th Asian Winter Games was held in Kazakhstan's capital city Astana and Almaty, the biggest city of the country, from January 30, 2011 to February 6, 2011. It was the first time Asian Winter Games was held in Kazakhstan and it was also the first time Kazakhstan hosted such a large event since its independence from the Soviet Union. Through holding such a global event as the Asian Winter Games, Kazakhstan managed to show its new international image and could prove its comprehensive national strength and great international influence in the political, economic, cultural, scientific, and technological fields. These are fields that are getting more powerful every day and need to be displayed to the whole world. The honor of holding Asian Winter Games also brought the host cities significant influence and notable benefits.

This article is mainly based on the perspective of tourists, with first-hand data that were collected by

\footnotetext{
* Acknowledgements: This study was supported by Grand Key Project of China National Social Science Fund (12\&ZD024), the Third Period of 985 to Whole Promotion of Social Science Research at Fudan University (2012SHKXYB002), and China National Nature Science Funds (71073029\&70873025).

Guo Yingzhi, Ph.D., professor, Department of Tourism, Fudan University.

Li Xiaoming, Ph.D. candidate, Department of Tourism, Fudan University.

Daizy Liu, master candidate, School of Management, Fudan University.

Correspondence concerning this article should be addressed to Guo Yingzhi, Department of Tourism, Fudan University, Shanghai 200433, China. Email: yingzhig@hotmail.com.
} 
questionnaire-based surveys to investigate tourists' participation as well as motivation, to evaluate the perception of Asian Winter Games. It also explores frequency of tourists' participation in sport tourism in the past years, motivation factors, and relationship among the impact factors. This was collected in order to provide government organs with indicators of when they should hold sport events, valuating the various types of profits and benefits, and how to attract more tourists to participate, in order to better facilitate and promote the development of sport tourism, while providing a scientific basis for future reference.

Through using an empirical investigation of the tourists' influence perception evaluation in Kazakhstan Asian Winter Games, this study provided a scientific basis for past and future references. The results of the study could also be used to provide government organs with indicators of when they should hold sport events, valuating the economic, social etc. various types of profits and benefits, in order to better facilitate and promote the development of sport tourism.

The influence perception and the number of tourists participating in Asian Winter Games in recent years and whether it will affect tourism motivation were investigated in order to better facilitate and stimulate sport tourism motivation and participation in the sport tourism and so be able to understand tourists' real needs, in a way to meet their needs and build right marketing system and publicity model.

The detailed objectives of the study are as follows: (1) to get the demographic characteristics of the respondents through a descriptive analysis; (2) to extract the main factors of the motivation and influence perception of the respondents on the Asian Winter Games through the exploratory factor analysis; (3) to verify the results of the exploratory factor analysis and get the effective variables and factors of motivation and influence perception on the Asian Winter Games through confirmatory factor analysis; and (4) to build a structure equation model from the perspectives of three variables, such as tourist' motivations and influence perception on the Asian Winter Games and the times that tourists have participated in sport tourism in the past two years, aiming at exploring the internal connections of the three variables and testing the three hypotheses proposed in this study.

\section{Literature Review}

\section{Definition and Classification of Sport Tourism}

The concept of sport tourism emerged in the late 1880s. Victor Black first combined sport and tourism together in a book in 1887. Hall (1992) defined sport tourism as travel for non-commercial reasons, to participate or observe sporting activities away from the home range. Gibson (1999) defined sport tourism as travel with the main purpose of leisure, tourists attend fitness activities, or watch sport activities or visit attractions related to sport activities. While in terms of the purpose of sport tourism, Standeven and De Knop (1998) argued that sport tourism also includes the category of business and commercial tourism, namely, sport tourism can also occur while a person is traveling for business or commercial purposes. As for the forms of sport tourism, Standeven and De Knop (1998) identified several types of sport tourism according to the purposes and contents of the travel, namely, tourists can participate for holiday or for business, be active or passive, to observe or be involved in, to be organized or independent, and so on.

\section{Motivations of Sport Tourists}

As for the purposes of sport tourists, there are not only the purposes of general travel, which as American scholar G. Dann concluded, includes pull factors and pulling factors, sport tourism also involves some special 
purposes, such as fans and addicts in certain sports. Gibson, Willming, and Holdnak (2003) studied the motivations of fans as tourists to attend small-scale sport tourism events. Gibson (2005) made a study on the behaviors of sport tourists by reference to role theory, family life cycle theory, motivation theory, and the changes of social structure. Lisa, Heather, and Kenneth (2001) took the 1996 Atlanta Olympic Games as a case study and found that three most important factors affecting tourists' decisions in attending the sport events are: (1) an once-in-a-lifetime chance (29.7\%); (2) can solve the accommodation during the Olympic Games (11.3\%); and (3) can buy or acquire the Olympic Games tickets (8.4\%). And after making a decision, the biggest motivations to attend the Olympic Games were the wonderful sports competitions, culture experiences, and so on.

\section{Impacts of Sport Tourism}

International sport events always generate a great influence on the host countries and cities. Margaret (2007) analyzed the impacts of sport tourism on the basis of central place theory, stressing the influence of location features. Xiao, Shen, and Liu (2004) pointed out the influences of hosting large sport events on the host cities, such as enriching the tourism resources, improving the urban infrastructure, enhancing the cultural exchanges, etc.. A series of studies were done by Ritchie to access the impacts of the Olympic Games. Taking the 1988 Olympic Winter Games as a case study, positive impacts were found like boosting the economy, enhancing the international image and reputation of the host city. Vincent (1995) mainly studied the environmental impacts of the 1992 Winter Olympic Games, both positive and negative environmental impacts on the local city.

Hypotheses are as follows:

H1: The tourists' influence perception of the Asian Winter Games has a path effect on their motivation perception.

H2: The times that tourists have participated in sport tourism in the past two years have a path effect on their motivation perception of the Asian Winter Games.

H3: The times that tourists have participated in sport tourism in the past two years have a path effect on their influence perception of the Asian Winter Games.

\section{Methodology}

\section{Literature Review}

The authors make full use of the resources of the Internet, library, etc. and consult a large amount of domestic and foreign literature. Literature in Chinese and English includes studies on definitions and classification of sport tourism, studies on the tourists' motivations in participating in sport tourism, studies on the influence of sport tourism, studies on the current situation and development strategies of sport tourism, and case studies on some famous large sport games, such as the Olympic Games, the World Cup, etc..

\section{Marketing Survey}

The questionnaire was preliminarily designed based on the review of domestic and foreign literature. After a pilot study, the questionnaire was corrected. The questionnaires were distributed in Astana city, Kazakhstan, during the Asian Winter Games to visitors from January 30, 2011 to February 6, 2011, combined with an in-depth interview.

Questionnaire design. The questionnaire adapts the 5-point Likert scale, including three parts: The first 
part is aimed to tourists' influence perception survey within Kazakhstan Asian Winter Games, including the influence of five types of areas such as publicity, public benefits, economic benefits, social motives, and social costs; the second part is the survey about tourists' motivation to visit the Kazakhstan Asian Winter Games, including visiting motivation in seven aspects, such as cultural knowledge, enhancing the family relationship, seeking novelty, to escape from daily life, relaxing oneself, attractions of the Asian Winter Games, and souvenirs of the Asian Winter Games; the third part is a basic characteristic of respondents, including tourists' demographic characteristics, social attributes, etc..

Data collection. The random sampling survey method for data collection was used. The questionnaires were distributed and first-hand data about tourists' participation motivation were collected in Astana city, Kazakhstan, during the Asian Winter Games to visitors from January 30, 2011 to February 6, 2011, combined with an in-depth interview. Altogether, 300 questionnaires were collected in which 296 questionnaires were efficient.

Data analysis. The authors analyze the data with Statistical Package for Social Science (SPSS) statistics software, including descriptive analysis and principal component factor analysis, namely, exploratory factor analysis, confirmatory factor analysis, and structural equation modeling.

\section{Results and Discussion}

Firstly, according to the descriptive analysis of the social demographic characteristics of the sample, findings are as follows: The percentage of females (64.8\%) is far higher than males (35.2\%). In terms of the marital status, single and married respondents make up a similar amount, $49.5 \%$ and 50.5\% respectively. From the perspective of the times that respondents have participated in sport tourism in the past two years, most of the respondents have not been involved in sport tourism, and this part of tourists accounts for $43.4 \%$ of the respondents, which is close to half of the respondents, this is mainly because that few international sport events are held in Kazakhstan, while foreign countries that hold sport events are far away from Kazakhstan, which makes it not convenient for Kazakhstan residents to access. In terms of age, respondents who are 21-30 years old make up the main group, whose proportion is as high as $44.9 \%$, namely, most of the respondents are young people. As for the occupation, the proportion of the civil servants is the highest, which is $28.6 \%$, followed by that of professional technicians and students. In terms of the average family monthly income, more than half (57.7\%) of the respondents have a family month income of 20,000-99,999 Tenge ( 1 USD $=145$ Tenge), namely, the majority of the respondents are from middle-income families.

Secondly, seven motivation factors and six influence factors are extracted from the principal component analysis, namely, the factor analysis. Motivation factors include enhancing the family relationship, seeking novelty, seeking knowledge, leisure time, social communication, souvenirs of the Asian Winter Games, and participating in exhibition. Influence factors include economic benefits, social cost, social benefits, theme of the Asian Winter Games, catering accommodation conditions, and media publicity of the Asian Winter Games.

Thirdly, after a confirmatory factor analysis on the results of the exploratory factor analysis, the less reliable variables and factors are eliminated, the motivation and influence models are corrected, and the final models with better fitting degrees were built. Four motivation factors constitute the motivation factor model, including enhancing the family relationship, seeking novelty, seeking knowledge, and relaxing oneself; and four influence factors constitute the influence factor model, including economic benefits, social cost, social benefits, and theme of the Asian Winter Games. 
Fourthly, based on the results of the confirmatory factor analysis, which was constructed on the structural equation model (see Figure 1), it shows influence on the perception factors and on the number of tourists participating in sport tourism within the recent two years. The initial fit of the model was not good, but after amending it and adding improvements, the fit increased. It showed a relation among three sides, hence, it proved the initial hypothesis (H1) proposed in this paper, namely, the tourists' influence perception of the Asian Winter Games has a path effect on their motivation perception. It was found that the motivation for participating in Asian Winter Games had no significant correlation with their influence perception on the Asian Winter Games whether they had joined sport tourism events or not in the past two years. Therefore, through expanding sport events and festival tourism, which can increase the influence among the tourists, expanded publicity, enhancement of the positive impact, etc., tourists' motivation to participate in the Asian Winter Games could be stimulated. Therefore, it could stimulate tourists' motivation to participate in the Asian Winter Games by means of expanding publicity on the sport tourism events in order to enhance the positive impact and perception for tourists. Furthermore, the following conclusion can be drawn based on this structural equation model: The main motive of the respondents to participate in the Asian Winter Games was to improve sensation among family members and to pursue novelty. Tourists' attention for the impact of the Asian Winter Games is mainly on economic and social benefits that the Asian Winter Games can bring, so government departments and sport events and festival organizers are able to take measures accordingly. This can help increase innovation of sport tourism, provide suitability for family travelers, increase the publicity of the sport events theme context, expand the possible social benefits of the big sport events, can attract more tourists to attend sport events, and better promote the development of sport tourism.

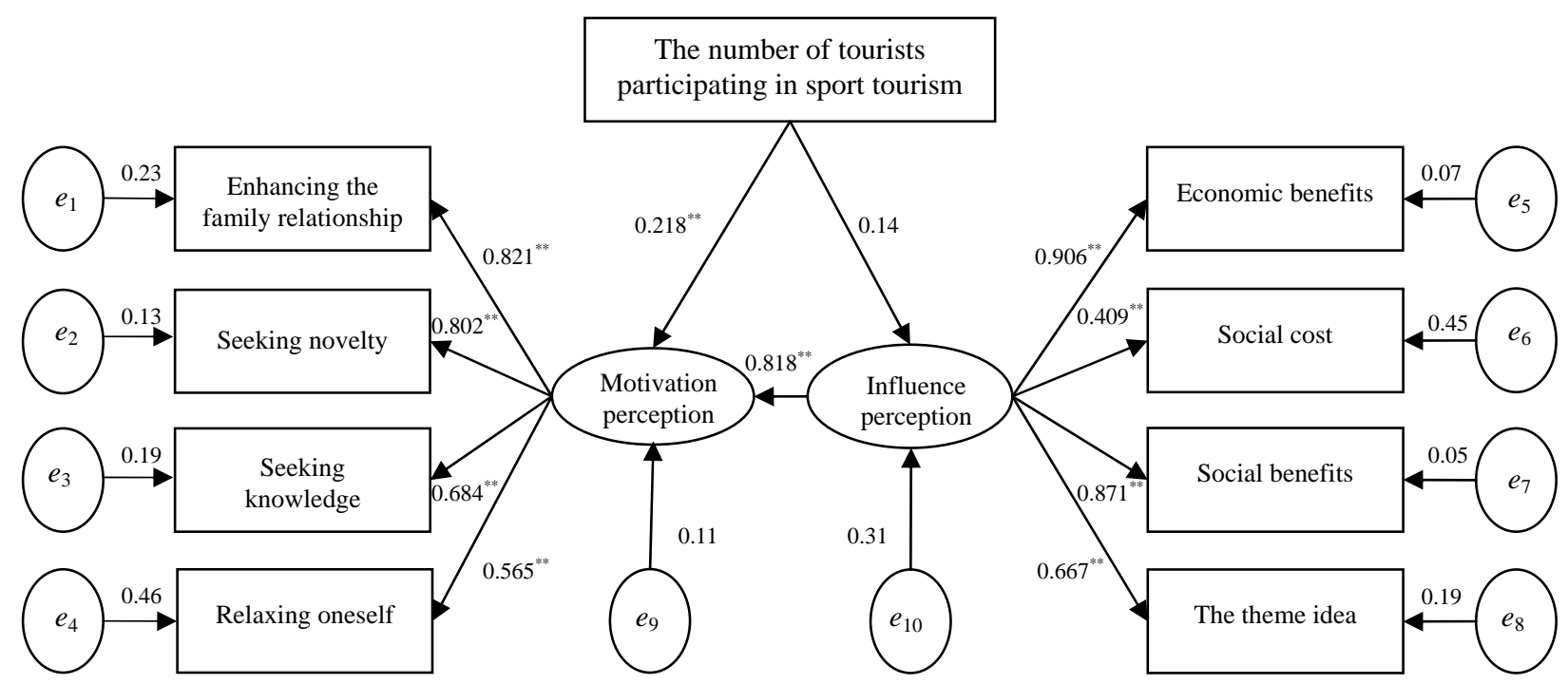

Figure 1. The structural equation model of this study. Note. ${ }^{* *}$ indicates significant at the level of $0.001 ; e_{1}-e_{10}$ are the measurement errors of each variable respectively.

Limitations of the study were as follows:

Firstly, based on the theoretical assumptions and empirical analysis, this study investigated tourists' participation motivation on the Asian Winter Games, the tourists' influence perception, and the number of tourists participating in sport tourism within the recent two years. The authors hope to be able to establish a 
reasonable structural equation model among the three sides, but at the same time neglected some other factors that may affect tourists' motivation and influence perceptions, such as tourists' revisit of the Asian Winter Games, their willingness to recommend to others, etc.. If we would add these factors, the structural equation could be more complete. Furthermore, the number of questionnaires could be further increased so as to balance the sample structure.

Secondly, this study only conducted a one-time market survey during the Asian Winter Games held in Kazakhstan. It is a static study on time profile, rather than a longitudinal research that focuses on the question's development and change in the duration time, so the survey results of motivation, influence perception of tourists taking part in the Asian Winter Games may be different between before and after the participation of the games. This research should continue to track market research and compare the survey results to the tourist that obtained before, during, and after the Asian Winter Games, in this way, the conclusions will be more persuasive.

\section{References}

Gibson, H. J. (1999). Sport tourism: A critical analysis of research. Sport Management Review, 1(1), 45-76.

Gibson, H. J. (2005). Towards an understanding of "why sport tourists do what they do". Sport in Society, 8(2), 198-217.

Gibson, H. J., Willming, C., \& Holdnak, A. (2003). Small-scale event sport tourism: Fans as tourists. Tourism Management, 24(2), 181-190.

Hall, C. M. (1992). Adventure, sport, and health tourism. In B. Weiler, \& C. M. Hall (Eds.), Special interest tourism (p. 194). London: Belhaven Press.

Lisa, D. N., Heather, A. B., \& Kenneth, C. T. (2001). Motivation to attend the 1996 Summer Olympic Games. Journal of Travel Research, 39(2), 327-331.

Margaret, J. D. (2007). Central place theory and sport tourism impacts. Annals of Tourism Research, 34(2), 332-347.

Standeven, J., \& De Knop, P. (1998). Sport tourism. Champaign: Human Kinetics Publishers.

Vincent, M. (1995). Environmental implications of the 1992 Winter Olympic Games. Tourism Management, 16(4), 269-275.

Xiao, F., Shen, J., \& Liu, J. (2004). Influences of hosting large sport events on the host city's urban tourism. Journal of Shenyang Institute of Physical Education, 23(6), 769-771. 